\title{
National Survey of Pharmacy and Therapeutic Committee in Saudi Arabia: Evaluation of Drug Formulary and Decision-Making
}

\author{
Yousef Ahmed Alomi* iD, The Former \\ General Manager of General Administration \\ of Pharmaceutical Care, The Former Head, \\ National Clinical Pharmacy and Pharmacy \\ Practice, The Former Head, Pharmacy R \& D \\ Administration, Ministry of Health, Riyadh, \\ SAUDI ARABIA. \\ Sultan Mohammed Al-Jarallah, Head, \\ Ambulatory Care Pharmacy, Oncology and \\ Hematology Clinical Pharmacist, Pharmaceutical \\ Care Department, Security Forces Hospital, \\ Riyadh, SAUDI ARABIA \\ Rasha Abdelsalam Elshenawy, BCS. Pharm. \\ BCPS (AQ-ID), CPHQ, M.Sc., TQM (AUC), SIDP, \\ CEO of FADIC, Ministry of Health, Makkah, \\ SAUDI ARABIA \\ Faiz A Bahadig Rph, (BSC-Pharm, MBA), \\ Informatics Pharmacist, Pharmaceutical Care \\ Department, King Abdulaziz Medical, \\ City-WR-Jeddah, Ministry of National Guard, \\ SAUDI ARABIA
}

\section{Correspondence:}

Dr. Yousef Ahmed Alomi, The Former General Manager of General Administration of Pharmaceutical Care, The Former Head, National Clinical pharmacy and pharmacy practice, The Former Head, Pharmacy R \& D Administration, Ministry of Health, Riyadh, SAUDI ARABIA

Phone no: +966504417712

E-mail:yalomi@gmail.com
Received: 21-03-2019;

Accepted: 05-05-2019

Copyright: (C) the author(s), publisher and licensee International Journal of Pharmacology and Clinical Sciences. This is an open-access article distributed under the terms of the Creative Commons Attribution Non-Commercial License, which permits unrestricted non-commercial use, distribution, and reproduction in any medium, provided the original work is properly cited.

This is an open access article distributed under the terms of the Creative Commons Attribution-NonCommercial-ShareAlike 4.0 License

Access this article online

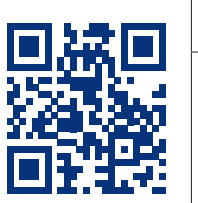

www.ijpcs.net

DOI:

10.5530/ijpcs.2019.8.51

\begin{abstract}
Objective: Ministry of Health $(\mathrm{MOH})$ hospitals in Saudi Arabia should develop, organize and administer a formulary system that follows the principles to optimize patient care by ensuring access to clinically appropriate, safe and cost-effective medications. This can be achieved through the Pharmacy and Therapeutic Committee's (PTC) role in the evaluation of hospital's drug formulary and decision-making. The primary purposes of the PTC are policy development, communication and education and formulary management. Therefore, in this study, we aimed to explore the hospital drug formulary evaluation and decision-making at $\mathrm{MOH}$ hospitals in Saudi Arabia. Methods: This is a 4-month cross-sectional national survey of PTC at MOH hospitals in Saudi Arabia. The survey consisted of two parts: the first part collected demographic information and the second part consisted on 93 questions divided into four domains. An electronic survey was distributed to all drug information centers at $\mathrm{MOH}$ hospitals and analyzed the evaluation of drug formulary and decision-making through the Survey Monkey system. Results: A total of 50 drug information centers responded to the questionnaire (100\%). Restricted drug usage (3.88), new drug entities (3.74), new dosage form (3.6) and new strength (3.6) were the majority of the requests for inclusion in the formulary. A total of 1-3 medications were evaluated monthly by the PTC at 41 (82\%) hospitals. Most of the healthcare providers were allowed to request for the addition or deletion of medications: PTC members 38 (76\%), attending medical staff 35 (70\%), pharmacy staff $10(20 \%)$ and formulary subcommittees 10 (20\%). The formal economic analysis of the drug formulary revision was rarely or never conducted at 26 (42\%) hospitals. The responsible person for the economic evaluation was drug information pharmacist (21 (42\%)), pharmacy department (nonspecific) (17 (34\%)) and the pharmacy and medical department (14 (28\%)). Conclusion: Evaluation of hospital's drug formulary and decision-making was not adequate at the majority of the hospitals. Education and training about drug evaluation with an emphasis on cost analysis and impact are mandatory. An electronic addition new medications with close formulary is required with close monitoring for all $\mathrm{MOH}$ hospitals in Saudi Arabia.

Keywords: National Pharmacy and Therapeutic Committee, Ministry of Health, Saudi Arabia, Evaluation, Drug Formulary, Decision-Making.
\end{abstract}

\section{INTRODUCTION}

The necessary policies and procedures that govern the PTCs are taken care by the administration of the drug formulary system in the healthcare institution. The American Society of Health-System Pharmacists (ASHP developed the guidelines and statements on the PTC and the drug formulary system. ${ }^{[1]}$ According to this guideline, the PTC is responsible for the administration of the drug formulary system. The essential organization of each healthcare setting and its medical staff are influenced by the specific functions and scope of the PTC. One of the elements of a drug formulary system that should also be included is the evaluation of the clinical use of medications (including outcomes). The development of policies and quality assurance activities for medication use and administration and the evaluation and monitoring of adverse drug reactions ADRs and medication errors should also be included. The PTC developed an evidence-based formulary of medications and medication-associated products accepted for use in the organization. The PTC should make revisions and maintain the formulary periodically. The PTC should encourage the rational, clinically appropriate, safe and cost-effective use of medications through guidelines and protocols. The PTC, on an ongoing basis, objectively appraised, evaluated and selected medications for the addition to or deletion from the formulary. ${ }^{[1]}$ The formulary systems and PTCs in the Western Pacific Region state that a large proportion of hospitals have implemented formularies and PTCs. Although formularies are commonly used, their effectiveness was limited, as formularies were not fits with standard treatment guidelines or the best available evidence. ${ }^{[2]}$ According to the WHO, the PTCs of public hospitals in rural Thailand have three main roles to play: 1) drug evaluation for the formulary, 2) drug policy and 3) drug monitoring system. Other PTC functions as recommended by the WHO in 2003 advise medical staff on all issues pertaining to drug use in the hospitals and developing or adopting standard treatment guidelines in addition to the dissemination of information to all medical staff in their hospitals. A previous study concluded 
that adopting these strategies will improve the overall effectiveness of PTCs and ensure that drug therapy was based on sound analytical decisions and proven performance. And. ${ }^{[3]}$ The national survey prioritizing DTC decisions had been done. As a result, the implementation of strategies may be incomplete and ineffective and may pose a risk of serious consequences in patient care. This study identified the domains or criteria of DTC decisions so that they may allocate scarce resources to the systematic implementation of important decisions. This raised the importance of exploring the hospital's drug formulary evaluation and decision-making at the $\mathrm{MOH}$ hospitals in Saudi Arabia. ${ }^{[4]}$ In South Africa, a study on the assessment of structure and activities of PTCs of public sector hospitals in Gauteng Province showed a lack of expertise on the application of pharmacoeconomic analysis and evidence-based decisionmaking in formulary management. The study also identified the limited ADR reporting in attaining rational use of medicines at all levels as the main challenge in the activities of the PTCs. The study concluded that future utilization programs should strengthen PTCs in specialized aspects of formulary management. ${ }^{[5]}$ A previous study explored the PTC activities and decisionmaking processes of hospital drug committees in Germany and the role of clinical pharmacologists in the PTCs. According to their results, German hospital drug committees vary considerably with respect to their function and control mechanisms of drug use. Most of the results of this study appreciated a more intensive exchange of current problems and treatment guidelines. Although clinical pharmacologists should support the process of pharmacotherapeutic decision making, experts in this field are often not involved in German hospital drug committees. ${ }^{[6]}$

\section{METHODS}

This is a 4-month cross-sectional national survey of PTC at MOH hospitals in Saudi Arabia. The survey consisted of two parts: the first part collected the demographic information and second the part consisted of 93 questions divided into four domains: domain 1: scope, structure and responsibilities; domain 2: formulary management system; domain 3: evaluation of drug formulary and decisionmaking, which includes the formulary management system, person(s) allowed to request drug additions, the members having the authority to enter or delete the names of drugs from the formulary, the economic analysis or cost impact evaluation as part of the formulary review and assessment of drug policies and procedures; domain 4: organization and management of committee meetings. The survey questions were derived from the previous literature, local regulation and ASHP standards of PTC and formulary system. ${ }^{[1,7-11]}$ We used a 5-point Likert response scale system with close-ended questions to obtain responses. The questionnaire was distributed to 50 drug information centers at the $\mathrm{MOH}$ hospitals. Hospitals of any size or capacity or any type of specialty were included in this study. The survey was prepared in an electronic format and it analyzed evaluation of drug formulary and decision-making through the Survey Monkey system.

\section{RESULTS}

A total of 50 drug information centers responded to the questionnaire. Of them, 48 (96\%) belonged to Saudi and 2 (4\%) belonged non-Saudi individuals. There were 16 (32\%) female and $34(68 \%)$ male responders. The highest level of education was Bachelor Degree in Pharmacy 23 (46\%), followed by Diploma in Pharmacy $(10(20 \%))$ and Master of Clinical Pharmacy $(9(18 \%))$ with more than 3 years of experience as pharmacist (45 (90\%)). The majority of the responders were PTC members (21 (43.8\%)) and vice-chairman (15 (31.3\%)) with a duration of $1-6$ years $(64 \%)$ in PTC membership (Table 1). Majority of the responders were from hospitals with 100-299 beds $28(56 \%)$ and had obtained accreditation from CBAHI (33 (66\%)), Saudi Commission of Health Specialties (15 (30\%)) and Joint Commission USA (13 (26\%)) (Table 2). Based on the type of request of medications, the formulary had mention of the restricted drug usage (3.88), new drug entities (3.74), new dosage form (3.6) and new strength medications (3.6). At least 1-3 drugs were evaluated monthly by the PTC (41 (82\%)) (Table 3). Most of the members of the healthcare system who approved the request for drug addition was the PTC members (38 (76\%)), attending medical staff $(35(70 \%))$, pharmacy staff $(10(20 \%))$ and formulary subcommittees (10 (20\%)). Most of the PTC members had the authority to add or delete the drug from the formulary: chief of drug information centers $(20(40 \%))$ and chief of pharmacy (13 (26\%)) (Table 4). A formal economic analysis of the revised drug formulary was rarely or never conducted at hospitals $(26(42 \%))$. The responsible person for the economic evaluation was drug information pharmacist (21 (42\%)), pharmacy department (nonspecific) (17 (34\%)) and pharmacy and medical department $(14(28 \%))$. The economic evaluation included the alternative cost of therapy $(27(54 \%))$ and drug acquisition cost and direct medical cost $(16(32 \%))$. The person to write most of the formulary review was chief of drug information center (21 (42\%)) and director of pharmacy (15 (30\%)) (Table 5). Majority of the revised drug policies and procedures with high scores was new medications policy (3.83) and revised established drug policy (3.76) (Table 6).

\section{DISCUSSION}

One of the main functions of the PTC is addition and deletion of medications from drug hospital formulary. The method of the function is explored explained elsewhere. ${ }^{[1,7]}$ However, in this study, we explored the method of decisionmaking by the PTC. According to the results, most of the formulary was review request and data of drug use because of the formulary need to setup prescribing privilege which not implemented in the hospitals. The other common request was for new medications, new dosage and new strength. This result is expected because all dosages and strengths of a medication were not available in the drug formulary. Normally, each request is specified with one drug and with exact dosage form and strength. Each PTC evaluated 1-3 drugs every month which means 12-36 medications were evaluated annually. At majority of the hospitals, all physicians with any position were allowed to fill the form and request the addition and deletion of medications. However, the PTC members and physician might request the medications, which was also reported in a previous study. ${ }^{[12,11]}$ The pharmacists were allowed to request the addition or deletion of medications, whereas nurses were rarely allowed to request for new medications. There is no regulation regarding prevention of any of healthcare providers to request the medications while in practice; the physician mainly requests the medications. The chief of drug information pharmacist and chief of pharmacy can affect to add or delete the medications. Despite that the pharmacist does not commonly request medications, the pharmacy was mainly found to accept or reject the medications. Education and awareness program for all healthcare providers about drug formulary policies and procedures are a must.

The economic drug evaluation not commonly used for decision making which was differ and lower than of previous study. ${ }^{[13]}$ There are no pharmacoeconomic programs not implemented at most of the $\mathrm{MOH}$ hospitals. The economic analysis was mainly conducted by the drug information pharmacist or by the nonspecific pharmacy staff and sometimes the pharmacy and medical departments collaborated in this matter. This is expected because pharmacists have little knowledge about the assessment of pharmacoeconomics, which might be because of their qualifications. As a result, the full economic assessment of the 


\begin{tabular}{|c|c|c|c|c|c|c|c|c|c|c|}
\hline Gender & $\begin{array}{l}\text { Response } \\
\text { Count }\end{array}$ & $\begin{array}{c}\text { Response } \\
\text { Percent }\end{array}$ & \multicolumn{3}{|l|}{ Number of beds at your hospital } & \multicolumn{3}{|c|}{$\begin{array}{l}\text { Response } \\
\text { Count }\end{array}$} & \multicolumn{2}{|c|}{$\begin{array}{l}\text { Response } \\
\text { Percent }\end{array}$} \\
\hline Male & 34 & $68.0 \%$ & \multirow{2}{*}{\multicolumn{3}{|c|}{$<50$}} & \multirow{2}{*}{\multicolumn{3}{|c|}{4}} & \multirow{2}{*}{\multicolumn{2}{|c|}{$8.0 \%$}} \\
\hline Female & 16 & $32 \%$ & & & & & & & & \\
\hline Answered question & 50 & & \multicolumn{3}{|l|}{$50-99$} & \multicolumn{3}{|c|}{6} & \multicolumn{2}{|c|}{$12.0 \%$} \\
\hline Skipped question & 0 & & \multicolumn{3}{|l|}{$100-199$} & \multicolumn{3}{|c|}{14} & \multicolumn{2}{|c|}{$28.0 \%$} \\
\hline Nationality & $\begin{array}{l}\text { Response } \\
\text { Count }\end{array}$ & $\begin{array}{l}\text { Response } \\
\text { Percent }\end{array}$ & \multicolumn{3}{|l|}{ 200-299 } & \multicolumn{3}{|c|}{14} & \multicolumn{2}{|c|}{$28.0 \%$} \\
\hline Saudi & 48 & $96.0 \%$ & \multicolumn{3}{|l|}{ 300-399 } & \multicolumn{3}{|c|}{5} & \multicolumn{2}{|c|}{$10.0 \%$} \\
\hline Non- Saudi & 2 & $4.0 \%$ & \multicolumn{3}{|l|}{$400-499$} & \multicolumn{3}{|c|}{4} & \multicolumn{2}{|c|}{$8.0 \%$} \\
\hline Answered question & 50 & & $500-599$ & & & & 2 & & $4.0^{\circ}$ & \\
\hline Skipped question & 0 & & $=$ or $>600$ & & & & 0 & & $0.0^{\circ}$ & \\
\hline Academic Qualification (s): & $\begin{array}{l}\text { Response } \\
\text { Count }\end{array}$ & $\begin{array}{c}\text { Response } \\
\text { Percent }\end{array}$ & Medical City & & & & 1 & & $2.0^{\circ}$ & \\
\hline Diploma. Pharmacy & 2 & $4.00 \%$ & Answered question & & & & 50 & & & \\
\hline Bsc. Pharmacy & 23 & $46.00 \%$ & Skipped question & & & & 0 & & & \\
\hline Master of Science & 10 & $20.00 \%$ & The hospital accreditation & & & & sponse & & Respo & \\
\hline Master Clinical Pharmacy & 9 & $18.00 \%$ & & & & & Lount & & Perce & \\
\hline Doctor of Pharmacy & 10 & $20.00 \%$ & CBAHI & & & & 33 & & 66.0 & \\
\hline Two years Residency (R1) & 0 & $0.00 \%$ & Joint Commotion USA & & & & 13 & & 26.0 & \\
\hline Three years Residency (R2) & 0 & $0.00 \%$ & Canada & & & & 0 & & 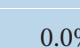 & \\
\hline $\mathrm{Ph} . \mathrm{D}$ & 2 & $4.00 \%$ & 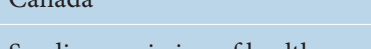 & & & & & & & \\
\hline M.B.A. & 1 & $2.00 \%$ & Saudi commission of health spec & Ities & & & 15 & & 30.0 & \\
\hline Other (please specify) & 1 & $2.00 \%$ & Non accredited & & & & 11 & & 22.00 & \\
\hline Answered question & 50 & & Answered question & & & & 50 & & & \\
\hline Skipped question & 0 & & Skipped question & & & & 0 & & & \\
\hline Total years you worked as pharmacist & $\begin{array}{l}\text { Response } \\
\text { Count }\end{array}$ & $\begin{array}{c}\text { Response } \\
\text { Percent }\end{array}$ & & & & & & & & \\
\hline$>1$ year & 1 & $2.0 \%$ & & & & & & & & \\
\hline $1-3$ years. & 4 & $8.0 \%$ & & & & & & & & \\
\hline 4-6 years. & 10 & $20.0 \%$ & Tahle 3. The formulary mana & 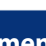 & 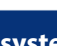 & & & & & \\
\hline$>6$ years. & 35 & $70.0 \%$ & Tabie 3 : ine tormulary manag & mein & syste & & & & & \\
\hline Answered question & 50 & & & & & & & & & \\
\hline Skipped question & 0 & & & & & $y$ & & & $\frac{\pi}{2}$ & อై \\
\hline Position in P\&T committee & $\begin{array}{c}\text { Response } \\
\text { Count }\end{array}$ & $\begin{array}{c}\text { Response } \\
\text { Percent }\end{array}$ & оํำ & $\frac{\text { बे }}{\frac{3}{4}}$ & 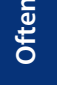 & है & 产 & $\frac{\mathrm{J}}{\mathrm{d}}$ & 这 & y. \\
\hline Chairman & 4 & $8.3 \%$ & है & & & & & & $\underset{\pi}{\mathscr{c}}$ & $\underset{\Psi}{\mathscr{y}}$ \\
\hline Vice-chairman & 15 & $31.3 \%$ & & & & & & & & \\
\hline Secretary & 6 & $12.5 \%$ & Review or approve new drug & 18 & 12 & 12 & 5 & 3 & 3.74 & 50 \\
\hline Coordinator & 2 & $4.2 \%$ & entities for formulary inclusion. & & & & & & & \\
\hline Assistant secretary & 2 & $4.2 \%$ & Review requests and trend data & 12 & 14 & 17 & 6 & 1 & 3.60 & 50 \\
\hline Committee member & 21 & $43.8 \%$ & on non-formulary drug use & & & & & & & \\
\hline Answered question & 48 & & Review or approve new dosage & 16 & 11 & 14 & 6 & 3 & 3.62 & 50 \\
\hline Skipped question & 2 & & forms for formulary inclusion & & & & & & & \\
\hline $\begin{array}{l}\text { Years of Experiences as a P\&T } \\
\text { committee member }\end{array}$ & $\begin{array}{l}\text { Response } \\
\text { Count }\end{array}$ & $\begin{array}{c}\text { Response } \\
\text { Percent }\end{array}$ & $\begin{array}{l}\text { Review requests and usage data } \\
\text { for restricted drug use. }\end{array}$ & 20 & 10 & 15 & 4 & 1 & 3.88 & 50 \\
\hline$>1$ year & 10 & $20.0 \%$ & & & & & & & & \\
\hline $1-3$ years. & 17 & $34.0 \%$ & Review or approve new & 15 & 14 & 11 & 6 & 4 & 3.60 & 50 \\
\hline 4-6 years. & 15 & $30.0 \%$ & formulary inclusion. & & & & & & & \\
\hline$>6$ years. & 8 & $16.0 \%$ & Eancun rend a netion & & & & & & & 50 \\
\hline Answered question & 50 & & answerea question & & & & & & & 50 \\
\hline Skipped question & 0 & & skipped question & & & & & & & 0 \\
\hline
\end{tabular}




\begin{tabular}{|l|c|c|}
\hline Table 4: Group(s) or person(s) allowed to request drug additions. \\
\hline Answer Options & $\begin{array}{c}\text { Response } \\
\text { Count }\end{array}$ & $\begin{array}{c}\text { Response } \\
\text { Percent }\end{array}$ \\
\hline Attending medical staff & 37 & $74.00 \%$ \\
\hline Pharmacy and therapeutics committee & 38 & $76.00 \%$ \\
\hline Pharmacy staff & 10 & $20.00 \%$ \\
\hline Formulary subcommittee & 10 & $20.00 \%$ \\
\hline Nursing staff & 2 & $4.00 \%$ \\
\hline Hospital administrators & 9 & $18.00 \%$ \\
\hline Only physicians & 1 & $2.00 \%$ \\
\hline answered question & & 50 \\
\hline skipped question & & 0 \\
\hline The Members had the authority to enter or delete the drugs from the \\
formulary & & \\
\hline Answer Options & Response & Response \\
\hline Chief of Drug Information Center & 20 & $40.0 \%$ \\
\hline Drug Information pharmacist & 5 & $10.0 \%$ \\
\hline Chief of Clinical pharmacy & 1 & $2.0 \%$ \\
\hline Clinical pharmacist & 1 & $2.0 \%$ \\
\hline Chief of Pharmacy & 13 & $26.0 \%$ \\
\hline Physician & 5 & $10.0 \%$ \\
\hline Medical director & 1 & $2.0 \%$ \\
\hline All members & & $6.0 \%$ \\
\hline Depending on meeting recommendations & 1 & $2.0 \%$ \\
\hline answered question & & 50 \\
\hline skipped question & & 0 \\
\hline
\end{tabular}

new drug evaluation did not exist in most of the $\mathrm{MOH}$ hospitals. Moreover, most of the financial information included in the evaluation were alternative cost of medication and cost of drug acquisition with the direct medical cost. These findings are expected and used only the primary economic information. They do not use pharmacoeconomic analysts for an instant cost-effective, cost-utility and cost of quality of life analyses. The chief of drug information center writes the complete drug formulary review, which is also reported in a previous study, ${ }^{[11]}$ whereas the chief of department of clinical pharmacy or clinical pharmacy staff rarely involved because they are mostly responsible for the decision-making of policies and procedures. There is no significant role of clinical pharmacists in the decision-making process of a drug formulary. Over the past information of decision-making of the PTC, the committee mostly revised new drug policies or revised the old existed policies, whereas therapeutic interchange system or off labeled drug used not discussed in the PTC at most hospitals because both systems not fully implemented at $\mathrm{MOH}$ hospitals. According to the ASHP guidelines on the PTC and the formulary system, policy review and revision should occur as new information becomes available and at regular intervals. ${ }^{[1]}$ According to the CBAHI standards, the role of the PTC is important in reviewing and approving the drugs in healthcare settings. ${ }^{[14]}$ The regional PTC-related decisionmaking procedures should be reviewed periodically at all $\mathrm{MOH}$ hospitals in the KSA.
Table 5: The economic analysis or cost impact evaluation as part of the formulary review.

\begin{tabular}{|l|l|c}
\hline Answer Options & Response Count & Respons
\end{tabular}

\begin{tabular}{|l|c|c|}
\hline Always & 7 & Percent \\
\hline Sometimes & 17 & $34.0 \%$ \\
\hline Rarely & 14 & $28.0 \%$ \\
\hline Never & 12 & $24.0 \%$ \\
\hline answered question & & 50 \\
\hline skipped question & & 0 \\
\hline The Group(s) responsible for economic analysis &
\end{tabular}

\section{\begin{tabular}{l|l|l}
\hline Answer Options & Response Count & Response
\end{tabular}}

\begin{tabular}{|l|l}
\hline & \\
\hline
\end{tabular}

Pharmacy department (nonspecific)

$34.00 \%$

Drug information pharmacist $42.00 \%$

Clinical pharmacist $20.00 \%$

Pharmacy plus another department 17 21 10

(e.g., hospital administration, purchasing, medical staff)

$28.00 \%$

\begin{tabular}{|l|l|l|}
\hline Pharmacy and Therapeutic members & 1 & $2.00 \%$ \\
\hline
\end{tabular}

\begin{tabular}{|l|l|l|} 
Medical supply pharmacist & 1 & $2.00 \%$ \\
\hline
\end{tabular}

Not specified

$12.00 \%$

answered question

skipped question

0

The Information included in cost analysis.

\begin{tabular}{|l|c|c|}
\hline Answer Options & Response Count & $\begin{array}{c}\text { Response } \\
\text { Percent }\end{array}$ \\
\hline Drug acquisition costs & 16 & $32.0 \%$ \\
\hline Alternative therapy costs & 27 & $54.0 \%$ \\
\hline Direct medical costs & 16 & $32.0 \%$ \\
\hline Indirect costs & 6 & $12.0 \%$ \\
\hline Resource impact & 4 & $8.0 \%$ \\
\hline Nonmedical costs & 6 & $12.0 \%$ \\
\hline Trade off between quality and costs & 4 & $8.0 \%$ \\
\hline Not applying & 9 & $18.0 \%$ \\
\hline answered question & & 50 \\
\hline skipped question & & 0 \\
\hline A person who usually writes the formulary review? & \\
\hline Answer Options & Response Count & Response \\
\hline Chief of Drug Information Center DI & & Percent \\
\hline pharmacist & 21 & $42.0 \%$ \\
\hline Drug Information pharmacist & 8 & $16.0 \%$ \\
\hline Chief of Clinical Pharmacy & 2 & $4.0 \%$ \\
\hline Clinical pharmacist & 2 & $4.0 \%$ \\
\hline Director of Pharmacy & 15 & $30.0 \%$ \\
\hline Physician Medical & 0 & $0.0 \%$ \\
\hline Physician Surgery & 0 & $0.0 \%$ \\
\hline Physician Pediatrics & & $0.0 \%$ \\
\hline Pharmacists & & $2.0 \%$ \\
\hline Pharmacy quality coordinator & & $2.0 \%$ \\
\hline answered question & & 50 \\
\hline skipped question & & 0 \\
\hline & & \\
\hline
\end{tabular}




\begin{tabular}{|c|c|c|c|c|c|c|c|}
\hline Answer Options & Always & Often & Sometimes & Rarely & Never & $\begin{array}{l}\text { Rating } \\
\text { Average }\end{array}$ & $\begin{array}{l}\text { Response } \\
\text { Count }\end{array}$ \\
\hline Review or approve new drug policies and procedures. & 16 & 14 & 16 & 3 & 1 & 3.82 & 50 \\
\hline Review established or revised policies and procedures. & 16 & 15 & 11 & 7 & 1 & 3.76 & 50 \\
\hline Review or approve specific therapeutic interchange procedure. & 11 & 12 & 13 & 9 & 5 & 3.30 & 50 \\
\hline $\begin{array}{l}\text { Review or approve sanctions against drug companies or } \\
\text { representatives }\end{array}$ & 11 & 8 & 14 & 12 & 5 & 3.16 & 50 \\
\hline Review or approve off-label use of medications policy & 13 & 7 & 13 & 12 & 5 & 3.22 & 50 \\
\hline answered question & & & & & & & 50 \\
\hline skipped question & & & & & & & 0 \\
\hline
\end{tabular}

\section{CONCLUSION}

The decision-making process of PTC at $\mathrm{MOH}$ hospitals is functioning very well. The complete pharmacoeconomic system is not entirely involved in PTC's decision-making process. Targeting education and training for all healthcare providers with an emphasis on PTC members is required. Periodic survey of the PTC decision-making is highly recommended in the KSA.

\section{ACKNOWLEDGMENT}

None.

\section{CONFLICT OF INTEREST}

None.

\section{ABBREVIATIONS}

PTC: Pharmacy and therapeutic committee; UK: United Kingdom; MOH: Ministry of Health; DTC: Drug and therapeutics committees; ASHP: American Society of Health-System Pharmacists; WHO: World Health Organization; ADR: Adverse drug reaction; KSA: Kingdom of Saudi Arabia.

\section{ORCID ID}

Yousef Ahmed Alomi org/0000-0003-1381-628X

\section{REFERENCES}

1. Tyler LS, Cole SW, May JR, Miliares M, Valentino MA, Vermeulen LC, et al. ASHP Guidelines on the Pharmacy and Therapeutics Committee and the Formulary System. Am J Heal Pharm. 2008;65(13):1272-83.

2. Penm J, Chaar B, Dechun J, Moles R. Formulary systems and pharmacy and therapeutics committees in the Western Pacific Region: Exploring two Basel Statements. Am J Heal Pharm. 2013;70(11):967-79.

3. Umnuaypornlert A, Kitikannakorn N. Performance of Pharmacy and Therapeutics Committees of Public Hospitals in Rural Thailand. Pharm Sci Asia. 2014;41(1):11-8.

4. Tan EL, Day RO, Brien JAE. Prioritising drug and therapeutics committee (DTC) decisions: A national survey. Pharm World Sci. 2007;29(2):90-6.

5. Matlala M, Meyer J, Gous A. Assessment of the structure and activities of pharmacy and therapeutics committees of public sector hospitals, Gauteng Province, South Africa. Annals of Global Health. 2015;(81):182-3.

6. Thürmann PA, Harder S, Steioff A. Structure and activities of hospital drug committees in Germany. Eur J Clin Pharmacol. 1997;52(6):429-35.

7. Abazia DT anderson P, Azzopardi LM, Baker KR, Besier JL, Bootman JL, et al. ASHP statement on the pharmacy and therapeutics committee and the formulary system. Am J Heal Pharm. 2008;65(24):2384-6.

8. Alomi YA, Alghamdi SJ, Alattyh RA. National Corporate Pharmacy and Therapeutic Committee at the Ministry of Health, Saudi Arabia. Pharmacol Toxicol Biomed Reports. 2019;4(3):24-7.

9. Alomi YA, Alghamdi SJ, Alattyh RA. National Drug Formulary of the Ministry of Health in Saudi Arabia. Pharmacol Toxicol Biomed Reports. 2019;4(3):28-30.

10. American Society of Health-System Pharmacists Principles of a Sound Drug Formulary System. Best Pract Hosp Heal Syst Pharm. 2000;182-5.

11. Mannebach MA, Ascione FJ, Gaither CA, Bagozzi $\mathrm{RP}$, Cohen IA, Ryan ML. Activities, functions and structure of pharmacy and therapeutics committees in large teaching hospitals. Am J Heal Pharm. 1999;56(7):622-8.

12. GulW. PTC is important for the betterment of the hospital pharmacy. Innov Pharm Pharmacother. 2014;2(1):307-11.

13. Durán-García E, Santos-Ramos B, Puigventos-Latorre $F$, Ortega A. Literature review on the structure and operation of Pharmacy and Therapeutics Committees. International Journal of Clinical Pharmacy. 2011;33:475-83.

14. Saudi Center Board for Accreditation for Healthcare Institutions (CBAHI). Medication Management (MM). In: National Hospital Standards. $2^{\text {nd }}$ Editio. Saudi Central Board for Accreditation of Healthcare Institutions. 2016;194-211. 